\title{
PEMBELAJARAN PENYAKIT TERKAIT PERILAKU MEROKOK DAN EDUKASI UNTUK BERHENTI MEROKOK DI PENDIDIKAN DOKTER FAKULTAS KEDOKTERAN UGM
}

\author{
Yayi Suryo Prabandari \\ Fakultas Kedokteran, Universitas Gadjah Mada Yogyakarta
}

\begin{abstract}
Background: As the third big populous smoker country in the world, smoking-related diseases have become a major cause of death in Indonesia. Physician should play role in preventing tobacco epidemic. Therefore, the medical curriculum should prepare graduates who will be competent to explain the health effects of smoking behavior and help patients quit smoking. This study proposed to describe how far tobacco and smoking topic were thought in the medical school curriculum and assess student attitudes toward the necessity of physicians to routinely asked on smoking behavior, advice patients to stop smoking as well as the important of physician to receive smoking related diseases education in medical school. Method: The study was based on five separate cross sectional surveys carried out in 200, 2007, 2009, 2010 and 2011. Participants were 1696 students (733 males and 963 females) of Faculty of Medicine, Universitas Gadjah Mada (FM UGM). They were the Non-Problem Based Learning Curriculum (N-PBLC), the PBL Curriculum (PBL-C) and the Competency Based Curriculum (CBC) batches. Data was collected through a self-administered questionnaire. Descriptive analysis was used to present the data.

Results: Cigarettes smoking topic had been delivered in FM UGM by several lectures (N-PBLC students) and blocks (the PBL-C and the CBC students). The amount of 40,6\% to 83,5\% students in 5 years surveys reported that they had been trained on subjects that discussed the cigarette smoking topic. Topics on how to belp quit smoking reported lower (12,3\%$50 \%)$ than topic of tobacco related diseases or tobacco and public health. The majority of students mentioned that doctors should ask and give advice or patient' education (96,7\% - 99,8\%). More than $95 \%$ of students stated that the teaching that addresses cigarette smoking related diseases is important to be taught and trained in medical school.

Conclusion: Teaching and learning on the subject of cigarette smoking related diseases have been given, but needs to be improved, particularly on skills to help patients quit smoking.
\end{abstract}

Keywords: curriculum, tobacco related diseases, medical education

\section{ABSTRAK}

Latar Belakang: Sebagai negara dengan perokok terbanyak ke 3 di dunia, penyakit akibat rokok telah menjadi penyebab kematian utama di Indonesia. Dokter perlu berperan aktif dalam mencegah epidemi tembakau. Kurikulum di fakultas kedokteran seharusnya memuat pembelajaran yang mempersiapkan lulusan yang mempunyai kompetensi untuk dapat menjelaskan dampak kesehatan akibat perilaku merokok dan membantu pasien berhenti merokok. Tujuan penelitian ini adalah mendeskripsikan pengajaran yang membicarakan topik rokok di dalam kurikulum fakultas kedokteran dan mengukur sikap mahasiswa tentang keharusan dokter bertanya secara rutin kebiasaan merokok, menyarankan pasien untuk berhenti merokok serta kepentingan calon dokter untukmenerima pendidikan rokok dan akibatnya di fakultas kedokteran.

Metode: Penelitian ini didasarkan lima survei dengan rancangan potong lintang yang dilakukan pada tahun 2004, 2007, 2009, 2010, dan 2011 dan melibatkan 1696 mahasiswa (733 laki-laki dan 963 perempuan) Fakultas Kedokteran Universitas Gadjah Mada (FK UGM), baik yang mengikuti Kurikulum non Problem Based Learning (Kn-PBL), Kurikulum PBL (K-PBL) dan Kurikulum Berbasis Kompetensi (KBK). Pengumpulan data dilakukan dengan kuesioner tertutup yang diisi sendiri. Analisis data secara deskriptif.

Korespondensi: yayisuryo@ugm.ac.id 
Hasil: Pengajaran dan pembelajaran yang membicarakan topik rokok telah diberikan di FK UGM pada beberapa kuliah di kurikulum Kn-PBL serta beberapa blok dalam K-PBL dan KBK. Sebanyak 40,6\%-83,5\% mahasiswa pada 5 tahun survei melaporkan telah mendapatkan pengajaran yang membicarakan topik merokok. Topik tentang cara membantu berhenti merokok dilaporkan lebih rendah (12,3\%-50\%) daripada topik yang membicarakan rokok dan hubungannya dengan penyakit atau kesehatan masyarakat. Dokter seharusnya bertanya dan memberi nasihat serta edukasi menurut sebagian besar mahasiswa (96,7\%-99,8\%). Lebih dari 95\% mahasiswa menyatakan bahwa pengajaran yang membahas merokok serta akibatnya penting untuk diajarkan di fakultas kedokteran.

Kesimpulan: Pengajaran dan pembelajaran yang membicarakan topik rokok telah diberikan, namun perlu dioptimalkan, terutama tentang keterampilan untuk membantu pasien berhenti merokok.

Kata kunci: kurikulum, penyakit terkait merokok, pendidikan dokter

\section{PENDAHULUAN}

Indonesia merupakan negara dengan perokok terbanyak ketiga di dunia setelah Cina dan India, ${ }^{1}$ dan posisi ini telah bertahan beberapa tahun. Prevalensi perokok di Indonesia juga tidak pernah turun. Dalam jangka waktu satu dekade prevalensi merokok naik 7\%.2 Survei terakhir dari Global Adult Tobacco Survey (GATS) menunjukkan prevalensi perokok di Indonesia adalah 67\% laki-laki, 4,5\% perempuan dan total penduduk $36,1 \% .^{2}$ Seiring dengan prevalensi yang bertambah, penyakit yang terkait dengan penggunaan tembakau dan perilaku merokok juga meningkat. Kebiasaan merokok sebagai salah satu faktor risiko penyakit tidak menular (PTM) telah berkontribusi terhadap kematian. ${ }^{3}$

Seperti telah diteliti sejak lebih dari enam dekade yang lalu, kebiasaan merokok mempunyai dampak kesehatan yang beragam, mulai dari penyakit jantung, ${ }^{4}$ pembuluh darah, ${ }^{5}$ kanker, ${ }^{6}$ TB, ${ }^{7}$ Penyakit Paru Obstruktif Kronik $(\mathrm{PPOK}),{ }^{8}$ dan $\mathrm{WHO}^{1}$ menyebutkan lebih dari 20 penyakit berhubungan dengan kebiasaan merokok atau menggunakan tembakau. Risiko tersebut juga mengenai mereka yang tidak merokok namun terpapar asap rokok atau perokok pasif. Penyakit jantung iskemik juga berhubungan dengan perokok pasif. ${ }^{9}$ Kenaikan penyakit yang berhubungan dengan penggunaan rokok dari tahun ke tahun adalah sebagai berikut, neoplasma, stroke, diabetes. ${ }^{10}$ Kematian yang diakibatkan oleh penyakit yang terkait dengan kebiasaan merokok dari tahun ke tahun juga bertambah di Indonesia. ${ }^{11}$

Bila perilaku merokok tidak dicegah morbiditas dan mortalitas akibat tembakau dan merokok akan semakin meningkat, dan biaya kesehatan juga akan membesar, terlebih lagi sejak tahun 2014 jaminan kesehatan diberlakukan di Indonesia. Oleh karena itu beban kesehatan masyarakat ini perlu ditekan melalui pengendalian kebiasaan merokok, salah satunya adalah dengan melibatkan professional kesehatan, yaitu dokter. ${ }^{1}$ Dokter diharapkan berperan aktif dalam pencegahan dan penapisan untuk gaya hidup tidak sehat dan melakukan edukasi atau konseling untuk gaya hidup sehat.

Dalam kurikulum kedokteran sebelumnya ${ }^{12}$ promosi, edukasi dan konseling kesehatan juga telah masuk, demikian pula keharusan dokter untuk dapat melakukan kegiatan atau menganjurkan pencegahan penyakit. ${ }^{13}$ Penelitian yang dilakukan di Yogyakarta di tahun 2007 pada 690 dokter oleh $\mathrm{Ng}$ dkk. ${ }^{14}$ menemukan bahwa lebih dari 50\% dokter melaporkan telah memberikan nasehat untuk berhenti merokok pada lebih dari 30 pasien pertahun, namun hanya sedikit dokter yang bertanya secara rutin tentang kebiasaan merokok pasien (28\%).

Prabandari ${ }^{15}$ pada penelitian yang dilakukan pada dokter pelayanan primer (Puskesmas) di Yogyakarta dan Sleman pada tahun 2011 melaporkan bahwa 58\% dokter rutin bertanya tentang perilaku merokok, $30 \%$ rutin bertanya tentang kebiasaan makan sayur dan buah dan $32 \%$ rutin bertanya tentang kebiasaan melakukan olah raga. Sementara yang rutin menasehati untuk berhenti merokok adalah $77 \%$, menganjurkan makan sayur dan buah 55\% dan menasehati untuk melakukan olah raga 44\%. Menanyakan perilaku merokok sebagai bagian dari gaya hidup pasien adalah penting di negara maju. ${ }^{16}$ Dokter seharusnya bertanya dan lalu memberikan 
nasehat atau melakukan konseling untuk memodifikasi perilaku yang tidak sehat. ${ }^{17}$ Studi di US menunjukkan bahwa nasehat dokter dapat menjadikan pasien untuk berhenti merokok. ${ }^{18}$ Dalam review Cochrane ${ }^{19}$ disebutkan bahwa intervensi singkat yang dilakukan oleh dokter dapat membuat pasien berhenti merokok dan mempertahankan perilaku tidak merokoknya dalam satu tahun.

Peran dokter sebagai professional kesehatan dalam turut serta menekan PTM perlu dipersiapkan sejak dalam pendidikan. Kurikulum untuk penyakit terkait dengan perilaku merokok yang perlu diterapkan di fakultas kedokteran meliputi pemahaman tentang penyakit yang terkait dengan perilaku merokok dalam mekanisme dan patofisiologinya, pencegahan perilaku merokok dan pencegahan risikonya, serta cara untuk berhenti merokok. Dalam survei globalnya Richmond, et al. ${ }^{20}$ Melaporkan bahwa sebagian besar FK di seluruh dunia telah memperkenalkan kurikulum tentang penyakit yang terkait dengan tembakau.

Calon dokter juga harus menguasai intervensi singkat atau interview motivasional serta konseling berhenti merokok. Sebuah studi di US melaporkan bahwa pembelajaran tentang 5A (Ask, Advice, Assess, Assist dan Arrange) untuk intervensi singkat berhenti merokok yang diberikan di tahun pertama FK ternyata bertahan sampai tahun ke $4 .{ }^{21}$ Survei yang dilakukan pada mahasiswa kedokteran di Malaysia, India, Pakistan, Nepal dan Bangladesh melaporkan bahwa lebih dari $80 \%$ mahasiswa bertanya pada pasien tentang perilaku merokoknya selama di koas, namun hanya sepertiga di antara mereka yang melakukan konseling dan mengukur kesiapan pasien untuk berhenti merokok. ${ }^{22}$ Sejauh mana mahasiswa kedokteran di Indonesia bertanya sekaligus juga melakukan edukasi untuk berhenti merokok, serta menerima pembelajaran tentang penyakit terkait dengan perilaku merokok tentang pencegahan, mekanisme, patofisiologinya hingga pengendalian perilaku merokoknya belum banyak diteliti.

Penelitian ini bertujuan untuk mengetahui seberapa jauh topik tembakau dan perilaku merokok diajarkan di fakultas kedokteran. Selain itu penelitian ini juga ingin mengetahui sikap mahasiswa kedokteran tentang keharusan dokter bertanya secara rutin tentang kebiasaan merokok dan menyarankan pasien untuk berhenti merokok serta kepentingan calon dokter untuk menerima pendidikan tentang rokok dan akibatnya di fakultas kedokteran.

\section{METODE}

Penelitian ini dilaksanakan di FK UGM. Survei dilakukan pada tahun 2004, 2007, 2009, 2010, dan 2011. Selama kurun waktu tersebut, telah terjadi perubahan kurikulum dan strategi pembelajaran. Pada survei tahun 2004 mahasiswa FK UGM yang menjadi partisipan adalah lima angkatan dari dua jenis mahasiswa, yaitu mahasiswa dengan kurikulum PBL (K-PBL) untuk angkatan 1 dan 2, karena pada tahun 2002 FK UGM memberlakukan kurikulum PBL. Mahasiswa angkatan sebelumnya (angkatan tahun III-V) adalah mahasiswa Kn-PBL (memadukan kuliah dan PBL parsial). Selain ke dua jenis mahasiswa tersebut, pada survei tahun 2004, partisipan juga berasal dari mahasiswa yang telah menjalani kepaniteraan klinik. Dalam K-PBL, kurikulum disusun dalam sistem blok, yang terdiri dari enam modul/ skenario dan dijalankan selama enam minggu. Kurikulum S1 FK UGM pada saat tersebut terdiri dari 22 blok wajib dan satu blok elektif.

Survei di tahun 2007 juga terdiri dari dua jenis mahasiswa karena partisipan adalah mahasiswa tahun I, III dan IV (serta 3 orang mahasiswa tahun ke 5 yang mengikuti tutorial di tahun ke IV). Pada tahun 2006 terjadi perubahan kurikulum, meskipun tidak mengubah total, karena FK UGM mengikuti kurikulum pendidikan dokter nasional ke kurikulum berbasis kompetensi (KBK). Oleh karena itu survei di tahun 2007 diikuti mahasiswa K-PBL dan mahasiswa KBK. Survei di tahun 2009 diikuti oleh mahasiswa tahun ke II sampai dengan tahun $\mathrm{V}$, sehingga partisipan di survei ini juga terdiri dari dua jenis mahasiswa, yaitu mahasiswa K-PBL dan mahasiswa KBK. Survei di tahun 2010 dan 2011 diikuti oleh mahasiswa KBK.

Penelitian ini merupakan bagian dari proyek the Quit Tobacco International Research Project (QTI-RP), kerjasama antara FKUGM dengan Universitas Arizona, Universitas Minnesota, Universitas Kansas Missouri dan Sree Chitra 
Tirunal Institute for Medical Sciences and Technology, Trivandrum, Kerala, India. QTI-RP mempunyai tiga tujuan utama, yaitu penyusunan kurikulum tembakau dan rokok untuk fakultas kedokteran, pengembangan klinik berhenti merokok dan pengembangan masyarakat dengan rumah bebas asap rokok. Guna mencapai tujuan tersebut telah dilakukan beberapa survei sejak tahun 2004 sampai tahun 2011.

Survei pada mahasiswa FK UGM dilakukan pada tahun 2004, 2007, 2009, 2010, dan 2011 dengan rancangan potong lintang. Populasi penelitian adalah seluruh mahasiswa FKUGM dan tidak ada pengambilan sampel. Kriteria inklusi adalah mahasiswa aktif dan bersedia berpartisipasi. Kriteria eksklusi adalah mahasiswa yang tidak berpartisipasi secara penuh.

Kuesioner dibagikan pada saat awal tutorial dan asisten peneliti mengumpulkan kuesioner tersebut pada akhir tutorial pada setiap survei. Survei pada tahun 2004 melibatkan mahasiswa FK UGM dari tahun I sampai

kepaniteraan klinik dan partisipan adalah 571 orang, dengan rincian angkatan mahasiswa K-PBL 246 orang, Kn-PBL 248 orang, dan kepaniteraan klinik 77 orang. Survei tahun 2007 hanya melibatkan mahasiswa tahun 1, 3 dan 4 sebanyak 456 orang.Survei tahun 2009 sebanyak 530 mahasiswa tahun 1 sampai tahun ke-4 berpartisipasi. Pada survei 2010 dan 2011 response rate mahasiswa hanya 50\%, hanya 211 mahasiswa di tahun 2010 dan 262 mahasiswa di tahun 2011. Di kedua survei tersebut, hanya mahasiswa tahun 1 yang mengikuti dan beberapa mahasiswa tahun ke 2 yang mengikuti tutorial tahun 1 .

Variabel penelitian ini adalah topik merokok pada kurikulum fakultas kedokteran, persepsi terhadap keharusan dokter bertanya tentang perilaku merokok pasien dan memberikan nasehat pada pasien tentang berhenti merokok, serta penting tidaknya topik merokok pada kurikulum fakultas kedokteran. Variabel topik merokok pada kurikulum fakultas kedokteran diperoleh dari pertanyaan disinggung tidaknya topik merokok pada kuliah atau blok yang ada di FK UGM. Variabel persepsi diperoleh melalui pertanyaan terhadap keharusan dokter bertanya dan memberi nasehat tentang perilaku merokok pada pasien dengan pilihan jawaban "ya, pada semua pasien”, "ya, jika pasien bertanya”, “ya, jika mereka mempunyai penyakit yang berhubungan dengan merokok" dan "tidak, dokter tidak harus bertanya". Penting tidaknya calon dokter mendapat pembelajaran tentang topik merokok di kurikulum fakultas kedokteran mempunyai pilihan jawaban "sangat tidak penting", "penting", "tidak penting" dan "sangat tidak penting".

Data dikumpulkan melalui kuesioner terstruktur yang diisi sendiri. Kuesioner disusun oleh tim Quit Tobacco Indonesia (QTI) dalam bahasa Indonesia. Kuesioner tersebut merupakan adaptasi dari kuesioner kurikulum Tobacco related diseases in Medical School dan kuesioner Medical Student Tobacco Use Survei yang dikembangkan QTI-RP untuk digunakan di Indonesia. Sebelum diterjemahkan kembali ke bahasa Inggris, kuesioner diuji coba pada beberapa mahasiswa untuk uji keterbacaan sebagai langkah validitas muka. Kuesioner hasil adaptasi diterjemahkan kembali ke dalam bahasa Inggris dan dilakukan panel judgment dengan tim QTI-RP melalui workshop dan komunikasi via email untuk menegakkan validitas isi. Oleh karena sebagian besar pernyataan atau pertanyaan dalam kuesioner adalah faktual, tidak dilakukan uji analisis item. Data dianalisis secara deskriptif.

\section{HASIL DAN PEMBAHASAN}

Pada survei 2010 dan 2011 response rate mahasiswa hanya 50\%, hanya 211 mahasiswa di tahun 2010 dan 262 mahasiswa di tahun 2011. Di kedua survei tersebut, hanya mahasiswa tahun 1 yang mengikuti dan beberapa mahasiswa tahun ke 2 yang mengikuti tutorial tahun 1 . Pemaparan hasil survei pada tahun 2004 berdasarkan mahasiwa K-PBL kecuali pada tabel 3, karena kurikulum FK UGM telah bergeser ke pembelajaran berpusat pada mahasiswa. Tabel 3 memaparkan kuliah atau blok yang menyinggung topik merokok, sehingga perlu melibatkan mahasiswa Kn-PBLuntuk mendapatkan gambaran pembelajaran topik tembakau atau merokok dan dampak kesehatan sebelum masa pembelajaran di FK UGM KPBL.

Karakteristik partisipan survei dari tahun 2004 sampai survei tahun 2011 ditunjukkan pada gambar 1. Sebagian besar partisipan adalah perempuan dan dua survei (2007 dan 2009) melibatkan 4 angkatan. Survei tahun 2010 dan 2011 diikuti oleh sebagian besar mahasiswa tahun 
1 dan berusia di bawah 18 tahun, sementara survei 2004, berusia di atas 18 tahun. Sebagian besar partisipan adalah 2007 dan 2009 diikuti mahasiswa yang sebagian besar bukan perokok.

Tabel 1. Karakteristik partisipan penelitian tahun 2004-2011

\begin{tabular}{|c|c|c|c|c|c|c|c|c|c|c|}
\hline & \multicolumn{2}{|c|}{$\begin{array}{c}2004 \\
n=246\end{array}$} & \multicolumn{2}{|c|}{$\begin{array}{c}2007 \\
n=456\end{array}$} & \multicolumn{2}{|c|}{$\begin{array}{c}2009 \\
n=530\end{array}$} & \multicolumn{2}{|c|}{$\begin{array}{c}2010 \\
n=211\end{array}$} & \multicolumn{2}{|c|}{$\begin{array}{c}2011 \\
n=262\end{array}$} \\
\hline & $\mathrm{n}$ & $\%$ & $\mathrm{n}$ & $\%$ & $\mathrm{n}$ & $\%$ & $\mathrm{n}$ & $\%$ & $\mathrm{~N}$ & $\%$ \\
\hline \multicolumn{11}{|l|}{ Jenis Kelamin } \\
\hline Laki & 118 & 43,9 & 208 & 46,1 & 226 & 42,7 & 82 & 39,4 & 99 & 37,8 \\
\hline Perempuan & 128 & 56,1 & 243 & 53,9 & 303 & 57,3 & 126 & 60,6 & 163 & 62,2 \\
\hline \multicolumn{11}{|l|}{ Tahun } \\
\hline I & 108 & 43,5 & 157 & 34,8 & & & 205 & 98,6 & 259 & 98,9 \\
\hline II & 137 & 55,2 & & & 117 & 22,1 & 3 & 1,4 & 2 & 0,8 \\
\hline III & 1 & 0,4 & 170 & 37,7 & 164 & 30,9 & & & & \\
\hline IV & & & 121 & 26,8 & 123 & 23,2 & & & & \\
\hline $\mathrm{V}$ & & & 3 & 0,7 & 126 & 23,8 & & & 1 & 0,4 \\
\hline \multicolumn{11}{|l|}{ Umur } \\
\hline$<18$ tahun & 17 & 6,9 & 112 & 25,2 & 127 & 24,0 & 183 & 88,4 & 232 & 88,5 \\
\hline$>18$ tahun & 229 & 93,1 & 332 & 74,8 & 403 & 76,0 & 24 & 11,6 & 30 & 11,5 \\
\hline \multicolumn{11}{|l|}{ Status merokok } \\
\hline lidak pernah & 231 & 94,0 & 328 & 79,2 & 408 & 77,9 & 185 & 87,7 & 242 & 92,4 \\
\hline Mantan & & & 34 & 8,2 & 67 & 12,8 & 7 & 3,3 & 1 & 0,4 \\
\hline Occasional & & & 41 & 10,0 & 15 & 2,9 & 15 & 7,1 & 15 & 5,7 \\
\hline Teratur & 15 & 6,0 & 11 & 2,6 & 34 & 6,4 & 4 & 1,9 & 4 & 1,5 \\
\hline
\end{tabular}

Tabel 2 menunjukkan bahwa pembelajaran yang membahas topik penyakit yang terkait perilaku merokok dilaporkan telah diberikan selama mahasiswa belajar di FK UGM oleh sebagian besar mahasiswa pada seluruh survei, kecuali survei tahun 2004. Pembelajaran tentang cara membantu perokok berhenti merokok dilaporkan separuh dari mahasiswa partisipan survei 2009 dan 2011. Hanya sebagian kecil mahasiswa partisipan survei 2004, 2007 dan 2010 yang melaporkan bahwa mereka telah mendapat kuliah atau sesi khusus tentang cara membantu pasien untuk berhenti merokok. 
Tabel 2. Pengalaman pembelajaran topik merokok pada kurikulum FK UGM

\begin{tabular}{|c|c|c|c|c|c|c|c|c|c|c|}
\hline & \multicolumn{2}{|c|}{$\begin{array}{c}2004 \\
n=246\end{array}$} & \multicolumn{2}{|c|}{$\begin{array}{c}2007 \\
n=456\end{array}$} & \multicolumn{2}{|c|}{$\begin{array}{c}2009 \\
n=530\end{array}$} & \multicolumn{2}{|c|}{$\begin{array}{c}2010 \\
n=211\end{array}$} & \multicolumn{2}{|c|}{$\begin{array}{c}2011 \\
n=262\end{array}$} \\
\hline & $\mathbf{n}$ & $\%$ & $\mathbf{n}$ & $\%$ & $\mathbf{n}$ & $\%$ & $\mathbf{N}$ & $\%$ & $\mathbf{n}$ & $\%$ \\
\hline $\begin{array}{l}\text { Selama di FK UGM pernah mendapat } \\
\text { pendidikan tentang dampak tembakau } \\
\text { terhadap kesehatan } \\
\text { Tidak pernah } \\
\text { Pernah, namun tidak memadai } \\
\text { Pernah dan sudah memadai } \\
\text { Pernah dan sangat memadai } \\
\text { Saya tidak ingat }\end{array}$ & & & $\begin{array}{r}81 \\
135 \\
126 \\
44 \\
33\end{array}$ & $\begin{array}{r}19,3 \\
32,2 \\
30,1 \\
10,5 \\
7,9\end{array}$ & & & & & & \\
\hline $\begin{array}{l}\text { Ya } \\
\text { Tidak } \\
\text { lidak, karena baru saja mulai kuliah di l'K } \\
\text { Tidak yakin }\end{array}$ & $\begin{array}{r}74 \\
149 \\
23\end{array}$ & $\begin{array}{l}30,0 \\
61,0 \\
9,0\end{array}$ & & & $\begin{array}{r}439 \\
21 \\
66\end{array}$ & $\begin{array}{r}83,5 \\
4,0 \\
12,5\end{array}$ & $\begin{array}{r}96 \\
108 \\
7\end{array}$ & $\begin{array}{r}45,5 \\
51,2 \\
3,3\end{array}$ & $\begin{array}{r}185 \\
5 \\
72\end{array}$ & $\begin{array}{r}70,6 \\
1,9 \\
27,5\end{array}$ \\
\hline $\begin{array}{l}\text { Pernah mendapat sesi khusus/kuliah } \\
\text { tentang cara membantu orang berhenti } \\
\text { merokok } \\
\text { Tidak pernah } \\
\text { Pernah, namun tidak memadai } \\
\text { Pernah dan sudah memadai } \\
\text { Pernah dan sangat memadai } \\
\text { Saya tidak ingat }\end{array}$ & & & $\begin{array}{r}235 \\
92 \\
52 \\
11 \\
28\end{array}$ & $\begin{array}{r}56,2 \\
22,0 \\
12,4 \\
2,6 \\
6,7\end{array}$ & & & & & & \\
\hline $\begin{array}{l}\text { Ya } \\
\text { Tidak } \\
\text { Tidak, karena baru saja mulai kuliah di FK } \\
\text { Tidak yakin }\end{array}$ & $\begin{array}{r}31 \\
176\end{array}$ & $\begin{array}{l}12,6 \\
71,5\end{array}$ & & & $\begin{array}{r}288 \\
144 \\
95\end{array}$ & $\begin{array}{l}54.6 \\
27.3 \\
18.0\end{array}$ & $\begin{array}{r}26 \\
5 \\
180\end{array}$ & $\begin{array}{r}12.3 \\
2.4 \\
85.3\end{array}$ & $\begin{array}{r}136 \\
19 \\
107\end{array}$ & $\begin{array}{r}51.9 \\
7.4 \\
40.8\end{array}$ \\
\hline
\end{tabular}

Pembelajaran dengan topik rokok dan akibatnya telah dilaporkan oleh mahasiswa Kn-PBL (dapat dilihat pada tabel 3). Sebagian besar mahasiswa melaporkan bahwa mereka mendapatkan pembelajaran tentang perilaku merokok dan akibatnya di mata kuliah pra klinik pada kuliah IKM (Ilmu Kesehatan Masyarakat) diikuti dengan perilaku kedokteran dan patologi anatomi. Sementara itu mahasiswa yang telah menjalani kepaniteraan klinis melaporkan bahwa sebagian besar dari mereka mendapatkan materi merokok dan akibatnya di mata kuliah pra klinik pada IKM, kedokteran komunitas dan fisiologi. Pada mata kuliah klinik, sebagian besar mahasiswa kepaniteraan melaporkan mereka mendapatkan topik merokok dan tembakau pada bagian Ilmu Penyakit Dalam disusul THT, dan mahasiswa KnPBL mendapatkan sebagian besar di THT, disusul ilmu penyakit dalam. Mahasiswa K-PBL sebagian besar melaporkan mendapatkan materi perilaku merokok di blok IKM, disusul blok bioetika dan humaniora kedokteran. Aspek rokok dan dampaknya yang diberikan sebagian besar meliputi penyakit yang terkait dengan perilaku merokok $(23,2 \%)$, pencegahan perilaku merokok (16,3\%) dan epidemiologi merokok (15,5\%). 
Tabel 3. Pembelajaran dengan topik merokok atau tembakau pada kurikulum FK UGM sebelum dan di awal PBL pada survey di tahun 2004*

\begin{tabular}{|c|c|c|c|c|c|c|}
\hline & \multicolumn{2}{|c|}{$\begin{array}{c}\mathrm{K}-\mathrm{PBL} \\
(\mathrm{n}=246)\end{array}$} & \multicolumn{2}{|c|}{$\begin{array}{l}\mathrm{Kn}-\mathrm{PBL} \\
(\mathrm{n}=256)\end{array}$} & \multicolumn{2}{|c|}{$\begin{array}{l}\text { Kepaniteraan Klinik } \\
\quad(\mathrm{n}=77)\end{array}$} \\
\hline & $\mathrm{n}$ & $\%$ & $\mathrm{n}$ & $\%$ & $\mathrm{~N}$ & $\%$ \\
\hline \multicolumn{7}{|l|}{ Mata kuliah Preklinik } \\
\hline Anatomi & & & 15 & 7,2 & 8 & 14,0 \\
\hline Fisiologi & & & 68 & 32,5 & 19 & 33,3 \\
\hline Patologi anatomi & & & 121 & 57,9 & 17 & 29,8 \\
\hline Patologi klinik & & & 38 & 18,2 & 4 & 7,0 \\
\hline Kedokteran konnunitas & & & 54 & 25,8 & 19 & 33,3 \\
\hline Farmakologi & & & 27 & 12,9 & 8 & 14,0 \\
\hline Perilaku kedokteran & & & 132 & 63,2 & 16 & 28,1 \\
\hline Sosiologi kedokteran & & & 108 & 51,7 & 11 & 19,3 \\
\hline IKM & & & 134 & 64,1 & 42 & 73,7 \\
\hline \multicolumn{7}{|l|}{ Mata kuliah Klinik } \\
\hline Ilmu Penyakit Dalam & & & 61 & 29,2 & 47 & 82,5 \\
\hline THT & & & 74 & 35,4 & 25 & 43,9 \\
\hline IlmuBedah & & & 18 & 8,6 & 6 & 10,5 \\
\hline Nerologi & & & 16 & 7,7 & 10 & 17,5 \\
\hline Obsgyn & & & 29 & 13,9 & 6 & 10,5 \\
\hline Radiologi & & & 37 & 17,7 & 6 & 10,5 \\
\hline \multicolumn{7}{|l|}{ PBL } \\
\hline Keterampilan belajar dan Informatika kedokteran & 14 & 19,4 & & & & \\
\hline IKM & 51 & 70,8 & & & & \\
\hline Bioetik dan I Iumaniora Kedokteran & 16 & 22,2 & & & & \\
\hline Ncoplasma, degencrative dan proses regencrative & 8 & 11,1 & & & & \\
\hline
\end{tabular}

*Data didasarkan yang menjawab "Y a" pada setiap mata kuliah/blok dan persentase di table diambil yang > 10\%

Tabel 4. Modul tobacco related diseases yang dikembangkan oleh QTI*

\begin{tabular}{ll}
\hline No. & Title of Modules \\
\hline 1. & Tobacco issues in basic medical practice and professionalism \\
2. & Tobacco effect on cardiovascular system \\
3. & Tobacco effects on respiratory system \\
4. & Tobacco and neoplasm \\
5. & Tobacco and children's health \\
6. & Tobacco and adolescents \\
7. & Tobacco and gastrointestinal system \\
8. & Tobacco and community medicine and public health \\
9. & Tobacco and mental health \\
10. & Tobacco and reproductive system \\
11. & Tobacco and endocrine problem \\
12 & Tobacco and nervous system \\
13. & Tobacco and sensory organs \\
14. & Tobacco and musculoskeletal problems \\
\hline
\end{tabular}

- Seluruh modul dapat diunduh di www.quittobaccointernational.org dengan mendaftar secara gratis menjadi anggota. Modul berbahasa Inggris dan Indonesia dapat digunakan staf di FK manapun berada. 
Tabel 5. Topik tembakau dan rokok serta akibatnya di Fakultas Kedokteran UGM 2005-2011

\begin{tabular}{|c|c|c|c|c|c|c|c|c|c|}
\hline BLOK & & $\begin{array}{l}\text { TopikKuliah/ } \\
\text { Diskusi Panel }\end{array}$ & 2005 & 2006 & 2007 & 2008 & 2009 & 2010 & 2011 \\
\hline \multirow[t]{2}{*}{$\begin{array}{l}\text { Kurikulum PBI } \\
(2005-2007)^{\#}\end{array}$} & $\begin{array}{l}\text { Blok V (Ilmu Kese. } \\
\text { hatan Masyarakat \& } \mathrm{K} \\
\text { ewirausahaan) }\end{array}$ & $\begin{array}{l}\text { Health promotion } \\
\text { Behavior } \\
\text { modification) }\end{array}$ & $\begin{array}{l}\sqrt{ } \\
\sqrt{ }\end{array}$ & $\sqrt{ }$ & $\begin{array}{l}\sqrt{ } \\
\sqrt{ }\end{array}$ & & & & \\
\hline & $\begin{array}{l}\text { Blok VI (Bioetika \& H } \\
\text { umaniora) } \\
\text { Blok XVII (Keluarga } \\
\text { Berencana) }\end{array}$ & $\begin{array}{l}\text { Doctor as change } \\
\text { agents } \\
\text { Konseling }\end{array}$ & $\begin{array}{l}\sqrt{ } \\
\sqrt{ }\end{array}$ & $\begin{array}{l}\sqrt{ } \\
\sqrt{ }\end{array}$ & $\begin{array}{l}\sqrt{ } \\
\sqrt{ }\end{array}$ & $\sqrt{ }$ & $\sqrt{ }$ & & \\
\hline \multirow{10}{*}{$\begin{array}{l}\text { Kurikulum Berbasis } \\
\text { Kompetensi } \\
(2007-2013)^{*}\end{array}$} & $\begin{array}{l}\text { Blok 1-1 (Being medical } \\
\text { students and locomotor) }\end{array}$ & Professional behavior & & & $\sqrt{ }$ & $\sqrt{ }$ & $\sqrt{ }$ & $\sqrt{ }$ & $\sqrt{ }$ \\
\hline & $\begin{array}{l}\text { Blok 1-6 (Basic medical } \\
\text { practice) }\end{array}$ & $\begin{array}{l}\text { Risk behavior } 89 \text { its } \\
\text { prevention } \\
\text { Medical professional } \\
\text { behavior }\end{array}$ & & & $\sqrt{ }$ & $\sqrt{ }$ & $\sqrt{ }$ & $\sqrt{ }$ & $\begin{array}{l}\sqrt{ } \\
\sqrt{ }\end{array}$ \\
\hline & $\begin{array}{l}\text { Blok } 2.3 \text { (Infancy and } \\
\text { childhood) }\end{array}$ & $\begin{array}{l}\text { Second hand } \\
\text { smoking }\end{array}$ & & & & & $\sqrt{ }$ & $\sqrt{ }$ & $\sqrt{ }$ \\
\hline & Blok 2-4 (Adolescent) & $\begin{array}{l}\text { Smoking cessation } 8 \% \\
\text { prevention }\end{array}$ & & & & $\sqrt{ }$ & $\sqrt{ }$ & $\sqrt{ }$ & $\sqrt{ }$ \\
\hline & Blok 2.5 (Adulthood) & $\begin{array}{l}\text { Tobacco and } \\
\text { Schizophenia }\end{array}$ & & & & & & & $\sqrt{ }$ \\
\hline & $\begin{array}{l}\text { Blok } 3-2 \text { (Chest } \\
\text { complaint) }\end{array}$ & $\begin{array}{l}\text { Tobacco related } \\
\text { CVD } \\
\text { Tobacco related } \\
\text { respiratory }\end{array}$ & & & & & & $\begin{array}{l}\sqrt{ } \\
\sqrt{ }\end{array}$ & $\begin{array}{l}\sqrt{ } \\
\sqrt{ }\end{array}$ \\
\hline & $\begin{array}{l}\text { Blok 3-5 (Neurosensory } \\
\text { complaints) }\end{array}$ & $\begin{array}{l}\text { Pathophysiology and } \\
\text { Management of } \\
\text { Suroke } \\
\text { Pharmacotherapy } 88 \\
\text { Parkinson disease } \\
\text { Parkinson disease } \\
\text { Panel discussion of } \\
\text { Stroke }\end{array}$ & & & & & & & $\begin{array}{l}\sqrt{ } \\
\sqrt{ } \\
\sqrt{ }\end{array}$ \\
\hline & $\begin{array}{l}\text { Blok } 3.6 \text { (Lifestyle related } \\
\text { complaints) }\end{array}$ & $\begin{array}{l}\text { Current issue } 8 \\
\text { Management of } \\
\text { Diabetic Mellitus } \\
\text { Smoking cessation } \\
\text { Cost benefit of } \\
\text { healthy life style } \\
\text { Clinical Pathology } \\
\text { of Metabolic } \\
\text { Syndrome } \\
\text { Smoking related } \\
\text { Lung cancer } \\
\end{array}$ & & & & & & $\sqrt{ }$ & $\begin{array}{l}\sqrt{ } \\
\sqrt{ } \\
\sqrt{ }\end{array}$ \\
\hline & Blok Elektif & Smoking cesstion & & $\sqrt{ }$ & & $\sqrt{ }$ & & & \\
\hline & & $\begin{array}{l}\text { Smoking is a Magic } \\
\text { Bullet for Chronic } \\
\text { Disease }\end{array}$ & & & & & & & \\
\hline
\end{tabular}

\#Didasarkan dokumentasi penulis pertama pada kuliah pakar yang diberikan oleh penulis pertama

*Pada saat kurikulum berbasis kompetensi diperkenal di tahun 2006, kurikulum PBL awal untuk tahun lanjut masih berlangsung 
Pada tabel 5 dipaparkan kuliah dan blok yang membahas topik perilaku merokok dan akibat atau pencegahan dan cara pemberhentiannya. Olehk arena survei di tahun 2007, 2009, 2010, dan2 011 tidak ada pertanyaan tentang kurikulum secara detail, maka pemaparan didasarkan pada dokumen penulis dan pendataan dari program QTI. Selama kurun waktu 2004-2008 telah dikembangkan modul tobacco related diseases oleh QTI, kerjasama dengan QTI-RP yang dikoordinasi oleh Universitas Arizona, di AS. Beberapa modul (Tabel 4) yang dikembangkan lalu diperkenalkan pada tim kurikulum FK UGM. Setelah mendapat persetujuan dari tim kurikulum untuk dapat diintegrasikan, modul diperkenalkan pada beberapa tim blok yang terkait. Sebagian modul yang dikembangkan telah diintegrasikan di kurikulum FK UGM tahun 20082011.Modul yang terdiri dari beberapa modul mini (4-6 slide), referensi terkait, skenario, lembar fakta dan soal, yang dapat dipilih untuk diintegrasikan ke dalam satu topik kuliah dengan menawarkan modul lengkap atau modul mini kepada pengampu yang terkait.

Modul yang dikembangkan oleh QTI adalah modul dengan sistem Lego. ${ }^{23}$ Seperti permainan Lego yang dapat disusun dan dipecah menjadi beberapa bagian, modul yang dikembangkan oleh QTI yang dapat dipecah menjadi modul mini, sehingga pelaksanaan modul tidak harus secara keseluruhan. Pengampu dapat mengambil satu atau dua modul mini dan mengintegrasikan

ke dalam kuliahnya. Selain di FK UGM, QTI bekerja sama dengan FK UII dan FK UMY di Yogyakarta, serta FK Universitas Hasanudin di Makasar dan FK Universitas Sam Ratulangi di Manado.

Selama dalam pengembangan modul, beberapa topik perilaku merokok dan kesehatan telah menjadi bagian dari beberapa blok, terutama yang diampu oleh penulis pertama, bahkan sebelum ada projek QTI. Data pada tabel 3 menunjukkan bahwa mata kuliah Perilaku dan Sosiologi Kedokteran yang kebetulan diampu oleh penulis menunjukkan bahwa mahasiswa sebagian besar melaporkan bahwa topik perilaku merokok dan kesehatan telah disinggung dalam kuliah tersebut. Ada kemungkinan topik perilaku merokok dan penyakit telah diberikan di blok lainnya atau oleh pengampu kuliah yang lain, selain yang dipaparkan di tabel 5 pada tahun
2005-2008. Selain itu, topik perilaku merokok juga disinggung dalam skenario Blok 3-1 dan Blok 3-6 berdasarkan pengamatan pada buku modul.

Pada tahun 2006 dan 2008 telah ditawarkan Blok elektif dengan tema berhenti merokok. Blok elektif di tahun 2006 diberi tajuk "Smoking Cessation Elective Block". Blok ini diikuti oleh 30 orang mahasiswa tahun IV 2007 (angkatan 2004 K-PBL FK UGM) kelas reguler dan 10 mahasiswa tahun IV 2006 kelas internasional (di FK UGM terdapat dua jalur, kelas regular dan kelas internasional yang seluruh pembelajaran dilaksanakan dengan bahasa pengantar bahasa Inggris). Pada tahun 2007 blok elektif ini ditawarkan kembali, namun tidak ada mahasiswa yang berminat. Setelah melakukan sedikit revisi pada isi dan judul, pada tahun 2008 blok elektif ini ditawarkan kembali dan diikuti oleh 10 mahasiswa tahun IV 2008 kelas regular. Judul blok elektif di tahun 2008 adalah "Smoking Cessation is a Magic Bullet for for Better Management onTobacco Related Health Complaints".

Tabel 6 menunjukkan bahwa sebagian besar mahasiswa pada keseluruhan survei menganggap bahwa adalah penting dan sangat penting bahwa mahasiswa fakultas kedokteran menerima pendidikan tentang rokok dan akibatnya. Hampir semua mahasiswa juga mempunyai pendapat bahwa dokter harus bertanya secara rutin tentang kebiasaan merokok pasien. Sebagian besar mahasiswa, kecuali mahasiswa di survei 2011 menyatakan bahwa keharusan bertanya secara rutin tentang kebiasaan merokok diberlakukan pada semua pasien. Mahasiswa di survei 2011 lebih banyak yang berpendapat bahwa keharusan bertanya tentang kebiasaan merokok diberlakukan pada pasien yang mempunyai penyakit berhubungan dengan perilaku merokok. Hasil yang menarik dijumpai pada pernyataan tindakan menyarankan pasien untuk berhenti merokok merupakan tugas dokter. Hampir sebagian besar mahasiswa di semua survei (di kisaran 71\% - 84\%) menyatakan ya pada semua pasien. Pada survei 2004 sebesar $85 \%$ mahasiswa sangat setuju dan setuju untuk mendapatkan pengalaman praktis dengan pasien yang ingin berhenti merokok. Pertanyaan tersebut hanya ada di survei 2004, dan tidak diulang kembali di survei 2007, 2009, 2010 dan 2011. 
Tabel 6. Pendapat mahasiswa tentang pembelajaran topik merokok dan dampaknya

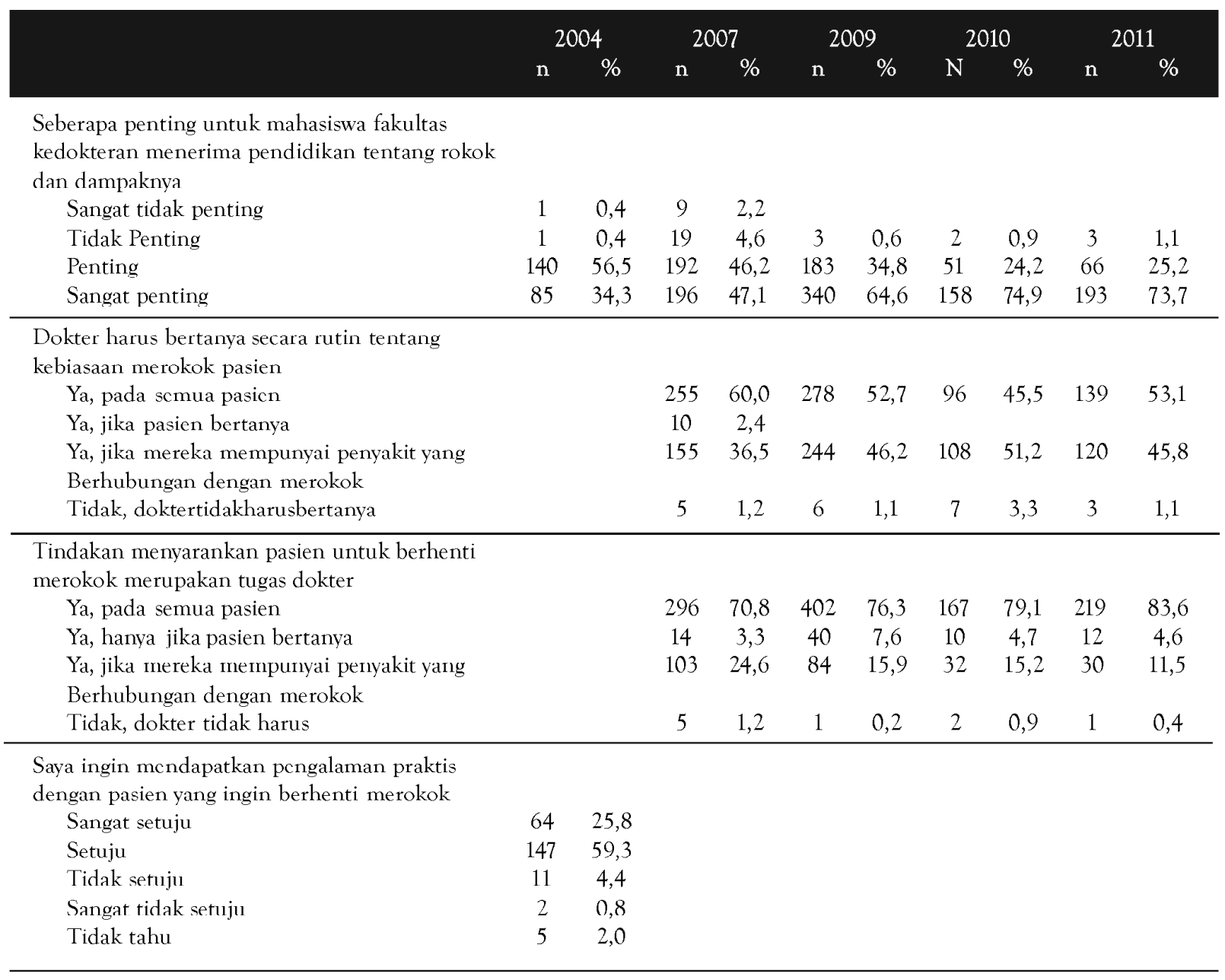

Persentase perokok di kalangan mahasiswa fakultas kedokteran dalam penelitian ini lebih rendah daripada yang dilaporkan dalam Global Health Professional Student Survei (GHPSS) yang dilaksanakan WHO di tahun $2008^{24}$ yang diikuti 49 negara anggota $\mathrm{WHO}$, studi di Berlin ${ }^{25}$ di tahun 2010 dan hampir setara dengan penelitian yang dilakukan di Malaysia, India, Pakistan, Nepal dan Bangladesh oleh Sreeramaredy dkk, ${ }^{22}$ pada tahun 2010. Dalam penelitian ini mahasiswa yang perokok teratur dan occasional (kadang-kadang) adalah sebanyak kisaran 6\%-12,5\%, dan GHPSS melaporkan bahwa prevalensi perokok di populasi mahasiswa kedokteran adalah sebesar 21\% (total laki-laki dan perempuan), penelitian Kusma dkk, ${ }^{25}$ di Berlin melaporkan 25\% dan penelitian Sreeramaredy melaporkan 13\%. Penelitian ini hampir serupa dengan yang ditemukan oleh Cape, Hannah dan
Sellman di tahun $2006,{ }^{26}$ prevelensi perokok mahasiswa kedokteran di New Zealand adalah 2,8\%-5,4\%. Prosentase perokok yang rendah dapat dimungkinkan karena mahasiswa fakultas kedokteran mayoritas adalah perempuan dan nilai masuk fakultas kedokteran termasuk tinggi, sehingga yang menjadi mahasiswa adalah pelajar pilihan. Hasil studi menunjukkan bahwa prestasi berhubungan dengan perilaku merokok. Prevalensi perokok ditemukan rendah dikalangan pelajar dengan prestasi tinggi. ${ }^{27}$

Mayoritas mahasiswa fakultas kedokteran dalam sepuluh tahun terakhir didominasi perempuan dan hal ini terlihat pula pada partisipan penelitian ini. Prosentase partisipan perempuan meningkat di survei tahun 2010 dan 2011. Usia masuk perguruan tinggi saat ini semakin muda dengan adanya akselerasi pada sekolah menengah. 
Pola ini terlihat, terutama pada survei di tahun 2010 dan dan 2011 yang diikuti oleh mahasiswa tahun pertama, sebagian besar mereka berusia di bawah 18 tahun.

Sepertiga mahasiswa yang di survei pada tahun 2004 melaporkan telah mendapatkan pembelajaran tentang topik merokok dan jumlah ini meningkat seiring dengan waktu. Pada survei di tahun 2007, sebanyak 40,6\% mahasiswa melaporkan telah mendapatkan pendidikan tentang dampak tembakau terhadap kesehatan dan merasa bahwa pendidikan tersebut memadai dan sangat memadai,meskipun 32\% juga menerima namun mereka

melaporkan bahwa pendidikan tersebut tidak memadai. Pada survei di tahun 2009, sebanyak 83,5\% mahasiswa melaporkan bahwa mereka telah mendapatkan materi tentang topik tembakau dan rokok, yang sayangnya pada survei di tahun 2010 persentase ini turun separuh lebih. Persentase mahasiswa yang menerima pendidikan tentang dampak tembakau meningkat kembali di tahun 2011 sebesar 70,6\%. Hasil penelitian sedikit di bawah persentase fakultas kedokteran di dunia yang memberikan pembelajaran mengenai tembakau. Richmond, dkk di tahun $1998^{20}$ melakukan survei kurikulum tembakau di fakultas kedokteran di seluruh dunia yang direspon 493 dekan fakultas kedokteran dari lima benua dan merepresentasikan 64\% negara dan $36 \%$ sekolah. Hasil penelitiannya menunjukkan bahwa terdapat $12 \%$ fakultas kedokteran di dunia yang tidak mengajarkan topik tembakau, dan persentase terbesar fakultas kedokteran di dunia yang tidak mengajarkan

topik tembakau adalah fakultas kedokteran di Afrika dan Asia sebesar 24\%. Sebagian besar pengajaran tentang topik tembakau disampaikan selama diskusi atau pengajaran (58\%). Sebanyak 40\% melakukan integrasi ke dalam modul dan hanya $11 \%$ melaporkan memberikan topik tembakau dalam format modul khusus.Penelitian yang dilakukan di Inggris di tahun $2004^{28}$ pada 24 fakultas kedokteran melaporkan bahwa 14 fakultas kedokteran (58\%) telah memasukkan topik rokok ataupun berhenti merokok di kurikulum mereka. Survei yang hampir sama dilakukan di Amerika pada tahun $2004^{29}$ di 12 fakultas kedokteran dan keduabelas fakultas kedokteran tersebut melaporkan bahwa 36\% course mereka telah memasukkan informasi tentang tembakau.
Respon mahasiswa menjawab "ya" pada pertanyaan pernah tidaknya mahasiswa mendapatkan sesi khusus/ kuliah tentang cara membantu orang berhenti merokok lebih rendah dibanding dengan pengalaman mendapatkan

pendidikan tentang dampak tembakau pada kesehatan. Hanya seperlima mahasiswa pada survei 2004, 2007 dan 2010 yang pernah mendapatkan sesi khusus/ kuliah tentang cara membantu orang berhenti merokok dan seperlimanya juga pada survei 2007 pernah mendapat sesi khusus atau kuliah tentang cara membantu orang berhenti merokok namun merasa kurang

memadai. Namun demikian, separuh mahasiswa pada survei 2009 dan 2011 melaporkan jika mereka pernah mendapatkan sesi khusus tentang cara membantu orang berhenti merokok. Sedikitnya mahasiswa fakultas kedokteran yang mendapatkan pendidikan untuk membantu pasien berhenti merokok juga ditemukan di beberapa penelitian sebelumnya. Richmond ${ }^{30}$ yang meneliti masuk tidaknya topik tembakau di kurikulum fakultas kedokteran di dunia melaporkan bahwa fakultas kedokteran di negara-negara barat lebih banyak memberikan pendidikan untuk membantu berhenti merokok daripada mahasiswa fakultas kedokteran di negara timur (44\% vs $28 \%$ ). Survei pada dekan fakultas kedokteran di Inggris menunjukkan bahwa hanya 40\% fakultas kedokteran yangmengajarkan tentang berhenti merokok. ${ }^{28}$ Dalam survei pada 217 dokter keluarga di Bahrain, ${ }^{31}$ dilaporkan bahwa hanya $4 \%$ dari mereka semasa pendidikan dokter yang mendapatkan pengajaran untuk membantu pasien berhenti merokok. Di Turki, ${ }^{32}$ hasil survei kurikulum tembakau melaporkan angka yang serupa dengan hasil survei 2009 dan 2011, yaitu $59 \%$ dan $62 \%$. Selanjutnya, survei di Italia ${ }^{33}$ pada 459 mahasiswa menunjukkan bahwa sebagian besar tidak mampu melakukan edukasi untuk berhenti merokok dan menatalaksana ketergantungan (addictive management). Berdasarkan penelitian ini dan penelitian terdahulu tampak bahwa pembelajaran atau pengajaran tentang dampak rokok dan tembakau pada kesehatan, demikian pula edukasi untuk membantu pasien untuk berhenti merokok belum dilaksanakan secara optimal. Pemahaman tentang mekanisme tembakau dan rokok mempengaruhi organ tubuh dan patofisiologi diperlukan 
untuk menjelaskan pada pasien tentang dampak perilaku merokok ataupun penggunaan tembakau.

Dalam teori Health Belief Model ${ }^{34}$ dijelaskan bahwa seseorang akan melakukan tindakan pencegahan ataupun pencarian pengobatan bila dia merasa dirinya rentan dan yang dilakukankannya dapat menyebabkan sakit ataupun bila telah sakit, keparahan penyakitnya akan dialaminya. Selanjutnya, pada langkah intervensi singkat berhenti merokok 5A (Ask, Advice, Assess, Assist dan Arrange) yang telah dilakukan di beberapa negara, dalam langkah advice dokter dapat menasihati pasien tentang akibat rokok yang akan memperparah keadaannya dan hal ini perlu dipelajari. Bila pemahaman tentang rokok atau tembakau dan akibatnya dipelajari di kurikulum fakultas kedokteran, bekal pengetahuan tersebut dapat memfasilitasi dokter dalam menjelaskan pada pasien.

Topik tembakau dan merokok serta akibatnya telah diberikan di FK UGM sejak beberapa waktu, karena pada survei tahun 2004 mahasiswa melaporkan bahwa topik merokok telah diberikan. Oleh karena survei tahun 2004 melibatkan mahasiswa K-PBL dan Kn-PBL, maka topik tembakau dan merokok serta akibatnya diberikan dalam bentuk kuliah (Kn-PBL) dan blok (K-PBL). Pada mahasiswa Kn-PBL topik tembakau dan merokok serta akibatnya persentase terbesar diberikan dalam kuliah ilmu kesehatan masyarakat/ IKM, disusul perilaku kedokteran, sementara mahasiswa yang di kepaniteraan klinik melaporkan terbanyak di IKM, disusul kedokteran komunikas dan fisiologi. Pada mata kuliah klinik terbanyak diberikan di THT (telinga hidung tenggorokan) dan IPD (Ilmu Penyakit dalam). Oleh karena survei tahun 2004 dilakukan pada saat mahasiswa K-PBL baru dua angkatan, maka blok yang diberikan baru di tahun pertama dan mahasiswa melaporkan bahwa persentasi terbesar blok yang menyinggung topik tembakau dan merokok serta akibatnya adalah blok IKM bioetik dan humaniora kedokteran serta keterampilan belajar dan informatika kedokteran. Hal yang sama dijumpai pada survei di tahun 2007 dan pengamatan pada kurikulum tahun 2005 dan 2006. Topik tembakau dan merokok serta akibatnya telah didiskusikan di blok V (IKM dan kewirausahaan), Blok VI (Bioetika dan Humaniora Kedokteran) serta blok XVII (Keluarga Berencana). Ada kemungkinan topik tembakau dan merokok serta akibatnya disinggung di blok lainnya, namun dalam kajian ini tidak dilakukan studi dokumen. Selanjutnya pada pengamatan di kurikulum FK UGM tahun 2008 sampai dengan 2011 beberapa topik tembakau dan merokok serta akibatnya telah diintegrasikan ke dalam blok di tahun I, II dan III. Beberapa penyakit yang terkait dengan perilaku merokok seperti CVD, stroke, Parkinson, diabetes militus dan sindrom metabolik serta kanker telah mengintegrasikan modul yang mendiskusikan perilaku merokok dan penyakit yang terkait. Topik berhenti merokok juga telah diintegrasikan ke dalam format panel diskusi di blok gaya hidup. Pada tahun 2006 dan 2008 telah dilaksanakan blok elektif tentang berhenti merokok.

Dalam survei tentang kurikulum tembakau di fakultas kedokteran di seluruh dunia Richmond et al. ${ }^{20}$ melaporkan bahwa sebagian besar fakultas kedokteran memberikan pengajaran tentang topik tembakau melalui kuliah dengan pendekatan non sistematik untuk mendiskusikan tembakau. Departemen yang bertanggung jawab untuk memberi pengajaran adalah kedokteran komunitas dan IKM (41\%) dan departemen paru (36\%). Pada penelitian tersebut juga dikemukakan bahwa topik tembakau yang persentasenya tertinggi dibahas di kurikulum fakultas kedokteran adalah penyakit terkait dengan tembakau (98\%), isu farmakologi dan komponen yang berbahaya pada tembakau dan rokok (71\%), efek perokok pasif (68\%), adiksi fisik dan psikologis yang dihubungkan dengan penggunaaan tembakau atau merokok (64\%), teknik berhenti merokok (39\%) dan perilaku merokok remaja (30\%). Hasil tersebut hampir serupa antara negara maju dan negara berkembang, hanya saja negara maju lebih banyak memberikan topik teknik berhenti merokok dan mendiskusikan psikologi adiksi. Penelitian yang dilakukan di Inggris menunjukkan hal yang hampir serupa. ${ }^{28}$ Sebagian besar topik yang diberikan dalam kurikulum kaitan tembakau, rokok dan kesehatan adalah risiko kanker, dampak kesehatan secara umum, perokok pasif, determinan merokok, isi rokok, farmakologi adiksi nikotin dan gejala pemutusan nikotin, kelompok risiko tinggi dan strategi populasi serta intervensi untuk berhenti merokok yang meliputi NRT (Nicotine Replacement Therapy), farmakologi dan intervensi singkat 5A. Pada penelitian yang dilakukan di 12 FK di Amerika, Powers 
$\mathrm{dkk},{ }^{29}$ melaporkan bahwa topik tembakau dan merokok telah didiskusikan di 41 dari 110 (tahun I) dan 92 (tahun II) kursus yang ditawarkan dengan metode pengajaran kuliah (didaktik), pelatihan dan aplikasi keterampilan serta berbasis web. Beberapa FK di US ${ }^{29}$ juga menawarkan kurikulum tembakau dan merokok sebagai kursus elektif dengan tema patologi adiksi, epidemiologi dan penyebab penyakit, epidemiologi pediatrik, prinsip konseling, farmakoterapi, isu khusus ibu hamil, kenaikan berat badan, budaya, gender dan umur serta kesehatan masyarakat. Pada penelitian terbaru yang dilakukan di tahun 2010 dan menyertakan Malaysia, India, Nepal, Pakistan dan Bangladesh, ${ }^{22}$ mahasiswa FK nya memberikan tingkat kepentingan topik rokok dan tembakau yang seharusnya diajarkan di FK, yaitu epidemiologi merokok dan tembakau, isi rokok, efek kesehatan perokok aktif dan pasif, adiksi nikotin secara fisik dan psikologis, panduan dan manfaat untuk berhenti merokok serta intervensinya, termasuk konseling, dan pencegahan kekambuhan. Mereka juga mengusulkan topik tentang regulasi dan pengendalian tembakau.

Sebagian topik rokok dan tembakau telah di integrasikan di dalam kurikulum FK UGM, meskipun belum selengkap yang diberikan di FK negara lainnya. Mengingat bahwa Indonesia adalah negara terbanyak perokoknya ke-3 di dunia dan penyakit yang terkait dengan perilaku merokok telah mulai menggeser penyakit infeksi, pengajaran tentang tembakau dan merokok perlu dipertimbangkan untuk mendapat porsi yang cukup tanpa menggeser kurikulum yang telah ada. Kesulitan mengintegrasikan ke dalam kurikulum yang telah ada ini berdasarkan pengalaman penulis adalah karena padatnya topik yang harus diberikan di seluruh blok. Padatnya kurikulum ini juga dijumpai sebagai kesulitan utama selain masalah administrasi dalam integrasi topik rokok dan tembakau di dalam kurikulum FK di Inggris. ${ }^{28}$ Sementara kesulitan lain yang dijumpai di negara maju adalah kesulitan dalam memotivasi mahasiswa, antusiasme staf, masalah administrasi, kurang pengetahuan dan pelatihan serta aturan dari pemerintah, sedangkan pada negara berkembang urutan terberat masalahnya adalah kurang pengetahuan dan pelatihan, kesulitan memotivasi mahasiswa, tembakau adalah hasil utama negara, penyakit lain yang harus ditekankan di kurikulum dan kekuatan industri tembakau. ${ }^{35}$ Hasil tersebut juga serupa yang dilaporkan oleh Richmond dan Taylor ${ }^{30}$ yang melakukan evaluasi pelaksanaan SEP (Smokescreen Education Program) di 27 FK di beberapa negara. Masalah yang terjadi adalah kurangnya minat staf untuk mengajarkan topik tersebut dan tidak adanya insentif dalam melakukan serta kurangnya pengetahuan untuk mengajarkan. Dalam penelitian tersebut juga dilaporkan beberapa faktor yang dapat mendorong terlaksananya SEP secara optimal, yaitu adanya staf kunci yang berminat untuk mengintegrasikan topik tembakau di kurikulum, identifikasi dosen yang akan mengajarkan dan mereka yang berminat datang dalam workshop persiapan kurikulum tersebut serta komitmen dekan dalam mengintegrasikannya.

Sebagian besar mahasiswa dalam survei 2004 sampai dengan 2011 menganggap penting bahwa mahasiswa fakultas kedokteran menerima pendidikan tentang rokok dan dampaknya, bahkan pada survei mahasiswa di tahun 2011, sebagian besar mahasiswa mengatakan sangat penting untuk mendapatkan pengajaran tersebut. Di survei pada tahun 2004, mayoritas mahasiswa FK juga ingin mendapatkan pengalaman praktis dengan pasien yang ingin berhenti merokok. Hasil tersebut serupa yang ditemukan pada survei yang dilakukan di Malaysia, Nepal, India, Pakistan dan Bangladesh..$^{22}$ Lebih dari 90\%mahasiswa menyatakan penting bagi dokter untuk mempunyai kompetensi untuk membantu pasien berhenti merokok dan lebih dari $80 \%$ mahasiswa juga mengatakan bahwa topik rokok (terutama epidemologi, efek perokok aktif dan pasif, gejala adiksi, manfaat dan teknik berhenti merokok) penting diajarkan di kurikulum FK. Selain itu, lebih dari separuh mahasiswa menyatakan bahwa edukasi merokok sebaiknya merupakan modul terpisah dari kurikulum, tidak hanya disinggung saja.

Sebagian besar mahasiswa FK UGM menyatakan bahwa dokter harus bertanya secara rutin tentang kebiasaan merokok pasien dan menyarankan untuk berhenti merokok pada semua pasien. Hasil ini mendukung penelitian pada mahasiswa di Malaysia, Nepal, India, Pakistan, Bangladesh, ${ }^{22}$ Turki, ${ }^{32}$ Italia, ${ }^{33}$ dan New Zealand. ${ }^{26}$ Anjuran agar dokter berperan aktif dalam pengendalian penggunaan tembakau telah dikemukakan dalam The World Tobacco Day di tahun 2005, di US telah 
dicanangkan sejak tahun $1996^{17}$ dan di Inggris sejak tahun 2000. ${ }^{28}$ Lebih lanjut, keharusan dokter untuk bertanya secara rutin tentang kebiasaan merokok pasien dan kemudian membantu pasien untuk berhenti merokok seharusnya menjadi bagian dari profesionalitas sebagai dokter. Hasil penelitian di Indonesia ${ }^{15,16}$ menunjukkan bahwa hanya sedikit dokter Puskesmas yang bertanya tentang kebiasaan merokok pasien. Penelitian di Italia ${ }^{33}$ melaporkan bahwa dokter seharusnya bertanya tentang kebiasaan merokok pada setiap kunjungan pasien, namun hanya sepertiga dokter di pelayanan primer yang memberikan edukasi untuk berhenti merokok. Dokter pelayanan primer di Bahrain ${ }^{31}$ sebagian besar (94\%) melaporkan bahwa profesional kesehatan yang seharusnya berperan dalam penatalaksanaan ketergantungan tembakau adalah psikolog dan yang memilih dokter untuk berperan hanya $46 \%$. Dokter di Inggris ${ }^{28}$ juga dilaporkan enggan untuk berdiskusi perilaku merokok pasien kecuali pasien menderita penyakit terkait dengan perilaku merokok. Hasil survei pada mahasiswa kesehatan di 16 negara melaporkan $87-99 \%$ dari mereka menyatakan bahwa profesi kesehatan sebaiknya menasihati pasien untuk tidak merokok namun persiapan untuk melakukan itu di pendidikan sangat minimal. ${ }^{36}$ Dalam GHPSS ${ }^{24}$ pada 49 negara dilaporkan bahwa $89 \%$ responden mengatakan bahwa mereka seharusnya menerima pelatihan formal konseling berhenti merokok untuk pasien, namun hanya $22 \%$ yang pernah menerima pelatihan formal untuk memberikan konseling berhenti merokok.

Menanyakan kebiasaan merokok dan memberikan edukasi atau nasihat untuk berhenti merokok sebetulnya merupakan bagian dari komunikasi dokter pasien. Menanyakan perilaku merokok yang merupakan salah satu perilaku tidak sehat adalah bagian dari eksplorasi kebiasaan dan kehidupan sosial pasien (atau umum disebut riwayat psikososial) yang harusnya ditanyakan setelah dokter menggali informasi gejala dan riwayat penyakit. ${ }^{37}$ Menasihati atau memberikan edukasi pada pasien, termasuk untuk berhenti merokok merupakan langkah menatalaksana atau intervensi. Dalam kurikulum pendidikan dokter yang terbaru penggalian riwayat dan edukasi terkait dengan gaya hidup termasuk kompetensi tingkat ke 4A, mahasiswa harus mampu untuk melakukan dibawah supervisi, untuk kemudian melakukannya secara mandiri pada pasien. Terbatasnya pendidikan yang terkait dengan gaya hidup sehat, termasuk perilaku merokok di dalam kurikulum, baik untuk pemahaman ataupun keterampilannya, dapat menyebabkan calon dokter kurang siap untuk menanyakan riwayat ataupun melakukan edukasi pada pasien. Dalam survei di Inggris ${ }^{28}$ dilaporkan bahwa kemampuan dokter untuk memberikan nasihat untuk berhenti merokok menurut para dokter 69\% mengatakan baik dan 28\% cukup, namun untuk kemampuan dalam hal teknik untuk membantu pasien berhenti merokok, 58\% mengatakan bahwa kemampuan mereka kurang. Penelitian di Italia ${ }^{33}$ melaporkan bahwa sepertiga mahasiswa menyatakan bahwa mereka merasa siap untuk membantu perokok berhenti merokok. Kompetensi untuk memberikan edukasi atau intervensi singkat sangat diperlukan oleh dokter untuk meningkatkan keinginan untuk merokok dan mempertahankan abstinen.

Penelitian ini mempunyai keterbatasan dalam hal response rate, terutama pada survei di tahun 2010 dan 2011. Kuesioner yang digunakan dalam survei tahun 2004 sedikit berbeda dengan survei tahun 2007 sampai dengan survei 2011, hal ini dapat mengancam validitas internal penelitian. Analisis dokumen kurikulum yang memuat topik tembakau dan rokok serta akibatnya tidak dilakukan secara mendalam, hanya didasarkan laporan dari QTI, sehingga kurang memperkaya pembahasan.

\section{KESIMPULAN}

Pengajaran dan pembelajaran tentang tembakau dan rokok serta dampaknya pada kesehatan, termasuk pencegahan dan edukasi untuk berhenti merokok telah diberikan di FK UGM, meskipun belum seperti yang telah dilakukan di fakultas kedokteran di negara maju. Materi tembakau dan rokok yang diajarkan kurikulum tahun 2004 dan sebelumnya, sampai dengan kurikulum tahun 2006 lebih banyak diberikan dalam kuliah atau blok ilmu kesehatan masyarakat, namun pada survei selanjutnya, materi penyakit yang berhubungan dengan perilaku merokok telah diberikan di blok lanjut (klinis). Mahasiswa fakultas kedokteran merasa penting untuk menerima pendidikan tentang rokok dan dampaknya serta mendapatkan pengalaman praktis dengan pasien yang ingin berhenti merokok. Mahasiswa juga menyatakan bahwa dokter harus bertanya secara rutin dan menyarankan pasien untuk berhenti merokok. 


\section{SARAN}

Pengajaran dan pembelajaran tentang tembakau serta akibatnya sebaiknya diintegrasikan ke dalam kurikulum fakultas kedokteran di Indonesia, seperti yang telah dicantumkan dalam SKDI ${ }^{38}$ terbaru tahun 2012 dalam pokok bahasan di area ke lima (Landasan Ilmiah Ilmu Kedokteran). Penjabaran area ke lima pada penyebab penyakit, terutama psikologis perilaku (5.2.c.), patomekanisme penyakit, yaitu nutrisi, lingkungan dan gaya hidup(5.3.j.), prinsip-prinsip pelayanan kesehatan primer, sekunder, dan tersier (5.6) serta prinsip-prinsip pencegahan penyakit terkait dengan gaya hidup (5.7) dapat mengintegrasikan topik tembakau dan perilaku merokok di dalamnya.

Pembelajaran disarankan tidak hanya kuliah dan hanya menjadi bagian kecil dari sebuah penyampaian, namun diberikan ruang yang cukup dan dilatih keterampilan untuk membantu pasien berhenti merokok, mengingat bahwa edukasi untuk berhenti merokok telah masuk ke dalam area enam keterampilan klinis pada SKDI 2012 di bagian 6.5 prinsip keterampilan terapetik. Keterampilan klinis edukasi untuk berhenti merokok di SKDI 2012 dicantumkan sebagai keterampilan 4A, yang berarti mahasiswa harus melakukannya sampai aplikasi edukasi berhenti merokok pada pasien. Mahasiswa perlu diberi peluang agar dapat berlatih dengan perokok atau pasien untuk berhenti merokok, mulai dari belajar di laboratorium keterampilan medis sampai dengan memberikan intervensi berhenti merokok di pelayanan kesehatan pada saat kepaniteraan maupun ke lapangan.

\section{UCAPAN TERIMA KASIH}

Penelitian ini merupakan salah satu aktivitas dari penelitian Quit Tobacco Indonesia (QTI) yang merupakan bagian The Quit Tobacco International Research Project (QTIRP) yang dibiayai oleh the Fogarty International Centre of US National Institutes of Health (R01TW005969-01). Proyek ini dilakukan di Indonesia dan India. Tidak ada conflict of interest. Penulis mengucapkan terima kasih kepada Prof. Harry Lando, Ph.D (Univ. of Minnesotta, USA) sebagai PIQTI-RP I dan Prof. Mark Nichter, Ph.D (Univ. of Arizona,USA) sebagai PIQTI-RP II, serta Dr.Nawi, $\mathrm{Ng}$ (Department Epidemiology, Umea University), Dra. Retna Siwi Padmawati, MA (FK UGM) dan dr. Jarir At
Thobbari, Ph.D (FK UGM), anggota peneliti dalam QTI untuk penyusunan alat ukur dan penatalaksanaan survei, serta para asisten peneliti, dr. Nur Azid Mahardinata (FK UGM), dr. Rusdi, Ph.D (FK UGM), dr. Wika Hartanti (FKUGM), dr. Arika Dewi MIM(QTI) sebagai pelaksana survey.

\section{DAFTAR PUSTAKA}

1. WHO. MPOWER. Jakarta: WHO; 2008.

2. Global Adult Tobacco Survei: Indonesia Report 2011. India: World Health Organization Regional Office for South-East Asia; 2012.

3. Global status report on non-communicable diseases 2010. Geneva: World Health Organization; 2011.

4. Tonstada S, Johnstonba A. Cardiovascular risks associated with smoking: a review for clinicians. Eur J Cardiovasc Prev Rehabil, 2006; 13:507-514.

5. Nakamura K, Barzi F, Lam TH, Huxley R, Feigin VL, Ueshima H,Woo J, Gu D, Ohkubo T, Lawes CCM, Suh I, Woodward M, for the Asia Pacific Cohort Studies Collaboration. Cigarette Smoking, Systolic Blood Pressure, and Cardiovascular Diseases in the Asia-Pacific Region Stroke, 2008; 39:1694-1702.

6. Kuper H, Adami HO, Boffetta P. Tobacco use, cancer causation and public health impact. Journal of Internal Medicine, 2002; 251: 455-466.

7. Chiang CY, Enarson K, Enarson DA. Associations between tobacco and tuberculosis. Int J Tuberc Lung Dis, 2007; 11(3):258-262.

8. Pelkonen M. Smoking: relationship to chronic bronchitis, chronic obstructive pulmonary disease and mortality. Current Opinion in Pulmonary Medicine. 2008;14:105-109.

9. Law MR, Wald NJ. Environmental Tobacco Smoke and Ischemic Heart Disease. Progress in Cardiovascular Diseases, 2003; 46 (1) July/August: 31-38.

10. Djaya S. Transisi epidemiologi di Indonesia dalamdua dekade terakhir dan implikasi pemeliharaan kesehatan menurut Survei Kesehatan Rumah Tangga, Surkernas, Riskesdas (1986-2007). Bul. Penelit. Kesehat. 2012; 40(3): 142 - 153.

11. NCD Country Profile. Geneva: WHO; 2012.

12. KIPDI III. Jakarta: Konsil Kedokteran Indonesia; 2006.

13. Konsil Kedokteran Indonesia. Standard Kompetensi Dokter Indonesia. Jakarta: Konsil Kedokteran Indonesia; 2010.

14. Ng N, Prabandari YS, Padmawati RS, Okah F, Haddock CK, Nichter M, Nichter M., Muramoto M, Poston WSC, Pyle S, Mahardinata N, Lando HA. Physician assessment of patient smoking in Indonesia: 
a public health priority. Tobacco Control, 2007; 16(3): 190-6.

15. Prabandari YS, Dewi A. Pola penggalian riwayat dan edukasi gaya hidup pada pasien berobat di Puskesmas Daerah Istimewa Yogyakarta: Sudah siapkah dokter Puskesmas menghadapi peningkatan prevalensi penyakit terkait gaya hidup. Prosiding Pertemuan Jaringan Epidemiologi Nasional. Solo, Sept 2012.

16. Noordman J, Verhaak P, and van Dulmen S. Discussing patient's lifestyle choices in the consulting room: analysis of GP-patient consultations between 1975 and 2008. Cited on 30 of December 2013. BMC Family Practice, 2010;11:87. Available from: http://www.biomedcentral. com/1471-2296/11/87.

17. Spangler JG, George G, Foley KL, Crandall SJ. Tobacco intervention training - current efforts and gaps in US medical schools. JAMA, Sept 2002; 288(9): 1102-1109.

18. Geller AC, Zapka J, Brooks KR, Dube C, Powers CA, Rigotti N, O’Donnell J, Ockene J. for the prevention and cessation education consortium. Tobacco control competencies for US medical students. Am J Public Health. 2005; 95(6):950-955.

19. Silagy C, Stead LL. Physician advice for smoking cessation. Oxford, England Cochrane Library,Update Software; 2001, issue 2.

20. Richmon RL, Debono DS, Larcos D, Kehoe L. Worldwide survey of education on tobacco in medical schools. Tob Control. 1998; 7:247-252.

21. Kosowicz LY, Pfeiffer CA, Vargas M. Long-term retention of smoking cessation counseling skills learned in the first year of medical school. Society of General Internal Medicine. 2007; 22:1161-1165.

22. Sreeramareddy CT, Suri S, Menezes RG, Kumar HNH, Rahman M, Islam MdR, Pereira XV, ShahM., Sathian B, Shetty U, Vaswani VR. Self-reported tobacco smoking practices among medical students and their perceptions towards training about tobacco smoking in medical curricula: A cross-sectional, questionnaire survey in Malaysia, India, Pakistan, Nepal, and Bangladesh. Substance Abuse Treatment, Prevention, and Policy 2010; 5:29.

23. Nichter M. Introducing tobacco cessation in developing countries: an overview of Project Quit Tobacco International. Tobacco Control. 2008; 15:12-17.

24. WHO. Global Health Professions Student Survey. Geneva: WHO; 2009.

25. Kusma B, Quarcoo D, Vitzthum K, Welte T, Mache S, Meyer-Falcke, Groneberg DA, Raupach T. A Berlin'smedical students' smoking habits, knowledge about smoking and attitudes toward smoking cessation counseling. Journal of Occupational Medicine and Toxicology 2010, 5:9.

26. Cape G, Hannah A, Sellman D. A longitudinal evaluation of medical student knowledge, skills and attitudes to alcohol and drugs. Addiction 2006; 101: 841-849.

27. Prabandari, YS. Smoking Inoculation to Prevent the Uptake of Smoking among Junior High School Students in Yogyakarta Municipality, Indonesia. Unpublished Doctorate Dissertation at the University of Newcastle, Australia; 2006.

28. Roddy E, Rubin P, Britton J. A study of smoking and smoking cessation on the curricula of UK medical schools. Tobacco Control, 2004; 13:74-77.

29. Powers CA, Zapka JG, Bognar B, Dube C, Ferry LH, Ferguson KJ, O’Donnell JF, Rigotti N, Thomson CC, White M, Wilkerson L, Geller AC, McIntosh S. Evaluation of current tobacco curriculum at $12 \mathrm{US}$ medical schools. Journal of Cancer Education 2004; 19(4): 212-19.

30. Richmond R, Taylor R. Global dissemination of tobacco curriculum in medical school. Int J Tuberc Lung Dis. 2006; 10(7):700-5.

31. Fadhil I. Tobacco education in medical schools: survey among primary care physicians in Bahrain Eastern Mediterranean Health Journal 2009; 15(4): 969.

32. Karlikaya C, Ozdemir L. Did unprogrammed tobacco control efforts over seven years decrease smoke prevalence in the medical school? Tuberkuloz ve Toraks Dergisi, 2011; 59(1): 18-26.

33. Grassi MC, Chiamulera C, Baraldo M, Culasso F, Ferketich AK, Raupach T, Patrono C, Nencini P. Cigarette Smoking Knowledge and Perceptions among students in four Italian Medical Schools. Nicotine \& tobacco research, sept 2012; 14 (9): 1065-72.

34. Glanz K, Rimer BK, Viswanath K. Health Behavior and Health Advice. San Fransisco, USA: Jossey-Bass, a Wiley Imprint; 2008.

35. Richmond $\mathrm{R}$. The process of introducing a tobacco curriculum in medical school. Respirology. 2004; 9:165-72.

36. Morbidity and Mortality Weekly Report (MMWR). Tobacco and cessation counseling - Global Professional Survey pilot study, 10 countries 2005. MMWR. 2005; 54:505-9.

37. Cole SA, \& Bird J. The Medical Interview. St. Louis: Mosby, 2000.

38. Konsil Kedokteran Indonesia. Standar Kompetensi Dokter Indonesia. Jakarta: KKI, 2012. 